\title{
Understanding UK construction professional services exports: definitions and characteristics
}

Article

Accepted Version

Jewell, C., Flanagan, R. and Anac, C. (2010) Understanding UK construction professional services exports: definitions and characteristics. Construction Management and Economics, 28 (3). pp. 231-239. ISSN 0144-6193 doi:

https://doi.org/10.1080/01446191003587729 Available at https://centaur.reading.ac.uk/17552/

It is advisable to refer to the publisher's version if you intend to cite from the work. See Guidance on citing.

To link to this article DOI: http://dx.doi.org/10.1080/01446191003587729

Publisher: Taylor \& Francis

Publisher statement: Author Posting. (c) Taylor \& Francis, 2010. This is the author's version of the work. It is posted here by permission of 'Copyright Holder' for personal use, not for redistribution. The definitive version was published in Construction Management and Economics, Volume 28 Issue 3, March 2010. doi:10.1080/01446191003587729 (http://dx.doi.org/10.1080/01446191003587729)

All outputs in CentAUR are protected by Intellectual Property Rights law, including copyright law. Copyright and IPR is retained by the creators or other copyright holders. Terms and conditions for use of this material are defined in the End User Agreement. 


\section{www.reading.ac.uk/centaur}

\section{CentAUR}

Central Archive at the University of Reading

Reading's research outputs online 


\title{
Understanding UK construction professional services exports: definitions and characteristics
}

\begin{abstract}
Services are very important to the UK balance of trade; a surplus has been recorded for trade in services every year since 1966. Construction professional services exports (CPS), which cover architecture, engineering and surveying (AES), have also increased, contributing over $£ 3 \mathrm{bn}$ to the UK trade balance in 2007. The changing environment of construction professional services exports complicates the validity of the characteristics and definitions of services as described in the research literature and official export statistics. Through semi-structured interviews undertaken with large consulting engineers and a round-table discussion with industry and government representatives, the research found that the impact of globalisation and the changes in the construction business environment, such as increasing foreign ownership and changing forms of procurement, are not fully reflected in the official statistics. There have also been rapid changes in technology, procurement and methods of delivery which have impacted exporting AES firms and a more appropriate set of characteristics is needed to better reflect the projectspecific and knowledge-intensive nature of AES firms.
\end{abstract}

Keywords: Exports, services, construction, globalization, knowledge-based economy

\section{Introduction}

The definition of services, their classification and measurement has prompted much debate, moving from being referred to as anything that is not a good to something much more complex. This paper is an overview of the research into services with a view to establishing how well the definitions and classifications apply to construction professional services. It looks at how researchers and economists have defined services over a period of time, focusing on both the definitions used in the literature and those used by 'official' bodies such as the United Nations, World Trade Organisation (WTO) ${ }^{1}$, Organisation for Economic Co-operation and Development (OECD) and national and international statistical 
offices. The UK Balance of Payments in the Pink Book ${ }^{2}$ (ONS, 2008) includes constructionrelated services under two headings - 'Construction' and 'Other business services'. The former covers 'work done on construction projects and installations by employees of an enterprise in locations outside the resident economic territory of the enterprise'. The latter includes architectural, engineering and other technical services being delivered overseas.

This research was prompted by the importance of CPS exports to the UK balance of trade. Discussions with UK professional organisations, government representatives, multinational companies and international bodies such as the OECD and the World Trade Organization, and semi-structured interviews undertaken with chief executive officers (CEOs) of UK firms have supported the authors' view that the area of CPS exports is under-researched. This gap in the body of knowledge is partly due to the rapidly changing international transactions in business environment and also that much of the professional services research has focused on other (non construction-related) professional services such as accounting, management consulting, law, IT and similar.

Von Nordenflycht (2009) undertook a review of publications (between 1990 and 2007) looking at the different types of professional services that had been cited. The constructionrelated professional services - engineering consulting/design, architecture and quantity surveying - were cited 16, 13 and 1 time(s) (respectively) out of a total of 30. Accounting, law and management consulting were cited 26, 26 and 25 times respectively. Von Nordenflycht's study highlights two issues. First, the problem of generalising and applying findings (from the literature) without being clear on the research focus; and second, the need for greater research in those areas which are not covered very well.

Architectural, engineering and surveying services may be found together in the official statistics, but they differ in their operations and strategies. The overlap between the construction-related services is increasing with changing forms of procurement and the growth in design and build, build-operate-transfer (BOT) and other integrated procurement approaches. This overlap is however not reflected in the official statistics because of the standard industrial classification systems used; systems that are based on international agreements for statistical methodologies.

\footnotetext{
${ }^{1}$ The WTO, formerly GATT, formulated the GATS (General Agreement on Trade in Services) Treaty in 1995
} 
This paper focuses on architectural, engineering and other technical services and defines CPS as those services provided by firms under Section M, Activity 71 of the UK SIC 2007 (ONS, 2007a); Architectural activities; Urban planning and landscape architectural activities; Engineering activities and related technical consultancy; Engineering design activities for industrial process and production, and; Other engineering activities. CPS differ from construction services in their industry classification and, they are classified as knowledgeintensive business services (KIBS), services that concentrate on their inputs of technology and human capital (Styles et al, 2005).

Research was undertaken by interviews and case studies with a sample of 16 leading UK construction professional service (CPS) firms in order to understand the types of service provided and their modes of delivery. These services are mostly supplied directly by providers in foreign markets and are associated with the international movement of capital and labour and accompanying knowledge. Professional services can also be traded by professionals travelling overseas (mode 4$)^{3}$ and cross-border (mode 1 ), or transmitted via the telecommunications networks being facilitated by advances in information communication technologies (ICT). Today's CPS firms operate very differently to just two decades ago, with changing forms of procurement, the increasing use of information and communication technologies and the impact of globalisation.

The paper is structured in three sections. The first section looks at the services literature, showing how services have been defined and classified since the $18^{\text {th }}$ century. The second section reviews how services are classified, looking in particular at the international and national classification schemes that are used in national trade statistics. The third section attempts to link the changing environment in which construction professional services firms export and draws some conclusions.

\footnotetext{
${ }^{2}$ Detailed annual estimates of UK balance of payments including estimates for the current account (Trade in goods and services, income and current transfers). The capital account, the financial account and the international investment position.

${ }^{3}$ World Trade Organisation, General Agreement on Trade in Services (GATS). Mode 1 - services supplied from one country to another (e.g. international telephone calls), officially known as "cross-border supply". Mode 2 - consumers or firms making use of a service in another country (e.g. tourism), officially "consumption abroad". Mode 3 - a foreign company setting up subsidiaries or branches to provide services in another country (e.g. foreign banks setting up operations in a country), officially "commercial presence". Mode 4 - individuals travelling from their own country to supply services in another (e.g. fashion models or consultants), officially "presence of natural persons"
} 


\section{Background}

The services sector is growing around the world and accounts for $70 \%$ of total employment and value added in OECD economies ${ }^{4}$. The sector is responsible for almost all employment growth in these economies (OECD, 2005). The G7 countries ${ }^{5}$ account for $45 \%$ of world exports of services (Brook, 2008). However, not all developed countries follow the same growth pattern. Japan shows a consistent deficit in its external trade in services (Eurostat, 2007). The World Bank's World Development Report (2009) shows the variance between high, middle and low income countries for value added services as a percentage of GDP. The world figure is $69 \%$ with the high, middle and low income countries being $72 \%, 59 \%$ and $48 \%$ respectively.

The UK has always been a strong trading nation, relying upon export manufactured goods to balance the import of raw materials. Since the 1970s there has been a strong growth of exports in professional services (ONS, 2009). This has helped to counterbalance the decline in exporting manufactured goods and the increase in importing manufactured products from low wage economies overseas and high tech products. The UK has seen a steady rise in its service exports; in 2005 they accounted for 8\% of world service exports (Brook, 2008). Employment in the UK, in the service industries represented $81 \%$ of total employment (in Q4 2008), with $21 \%$ of total employment in Finance and Business Services, the classification that includes architectural, engineering and surveying services. Services accounted for $12 \%$ of UK GDP in 2007, with construction professional services contributing $£ 3$ billion to the balance of payments, making it an important part of the economy, representing $45 \%$ of all service export balances and $15 \%$ of 'Other business services' (ONS, 2008). The CPS trade balance increased by 40\% between 1997 and 2007 (ONS, 2008). This increase was achieved in a period of continuing change in overseas business and global competition.

Globalisation is driving major changes in the way business is undertaken in the construction sector. The global economy has been transformed in recent years by the fall of international barriers to the flow of goods, services, capital and labour, and a marked acceleration in the pace of technological and scientific progress. The global sourcing of services, materials, components and labour is important in maintaining competitive advantage in an increasingly competitive marketplace. The pressures of competition in the

\footnotetext{
${ }^{4}$ Most of the 30 OECD members are high-income economies and are regarded as developed countries

${ }^{5}$ United States, Japan, Germany, France, United Kingdom, Italy and Canada
} 
domestic market from overseas and where firms have outgrown the domestic market mean there is a need to seek alternative markets, including overseas projects. The ease of crossborder trading and transferring services overseas has changed the nature of services trade, but have the services themselves changed? The following two sections look at the definitions and characteristics of a service from the perspective of services researchers.

\section{Previous Studies}

Services' impact on an economy is the main concern of business literature, mostly from an economic point of view as services are key to any economy as they are a major driver (Weissenberger-Eibel \& Koch, 2007). The status of services in economics has developed over the last two centuries, from the dismissive view of Smith (1776), Ricardo (1871) and Marx (1863) to recognition by researchers more recently that traditional manufacturing is no longer the key economic agent in a post-industrial society (Beyers, 1985), and that services industries are gaining importance.

Figure 1 shows a timeline of the economists and their theories on the definition of services. The timeline is divided into three eras of services research - "Out in the cold" (1766-1870); "Warming up" (between the world wars); and "Hot topic" (1970s to present).

\section{Out in the cold}

Classical economists such as Smith and Ricardo made a distinction between productive and unproductive labour, the doctrine of the physiocratic school of thought. People that work in the primary (agriculture) sector were seen as productive, whilst people providing services, such as domestic labour, were considered unproductive:

"The labour of a manufacturer adds, generally, to the value of the materials which he works upon, that of his own maintenance and of his master's profit. The labour of a menial servant, on the contrary, adds to the value of nothing. "Adam Smith (1776)

Karl Marx was similarly dismissive of services; in the Soviet Union and other communist countries, services were not even counted in the national output (Melvin, 1995). By the beginning of the 20th century there was a movement towards defining services as a distinct activity, rather than one that was 'tied' to manufacturing (Anderson \& Corley, 2002). 
Figure 1 A timeline of economic theories on services

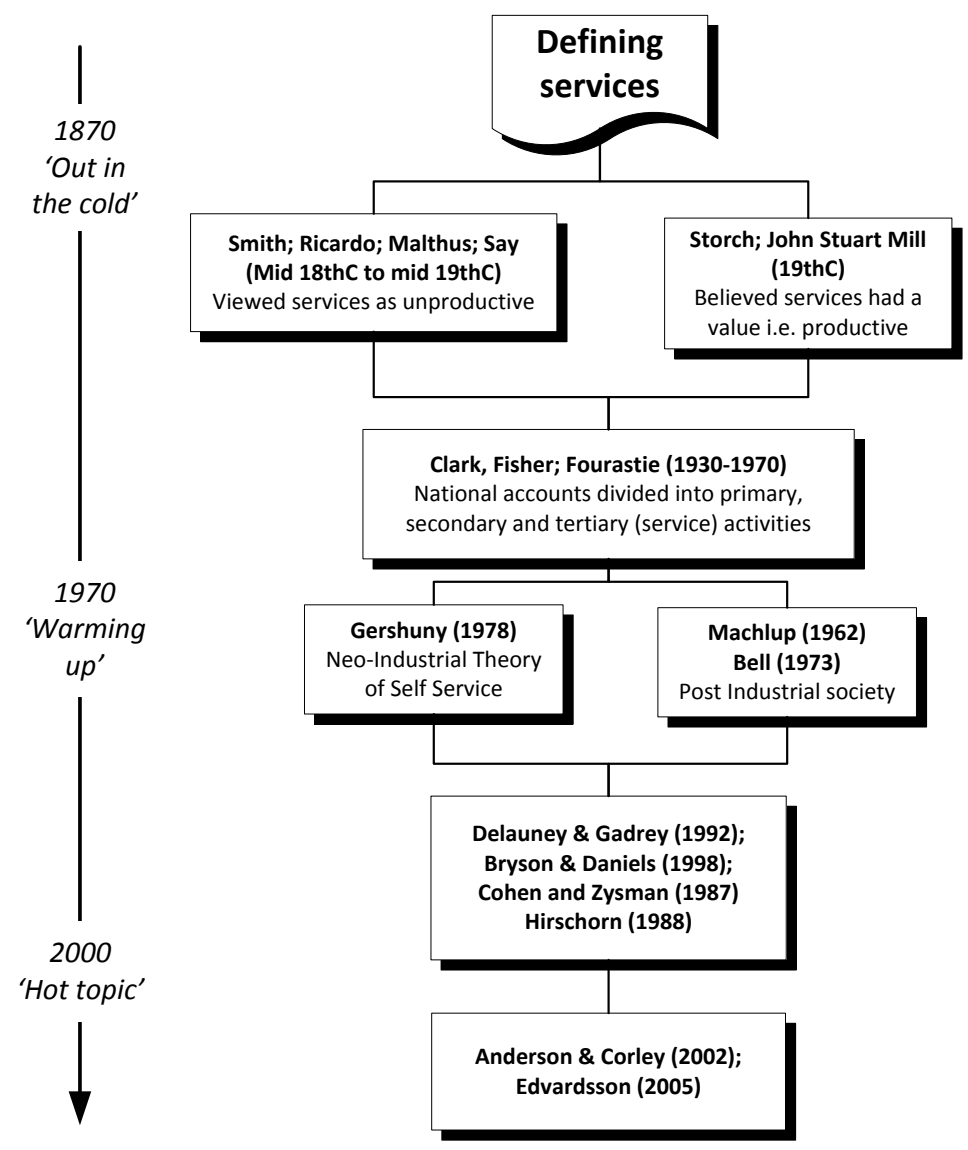

\section{Warming up}

In the 1930s and 1940s, Fisher (1935) and Clark (1940) developed theories to explain the growth in services. Fisher applied the term 'tertiary' to service industries, while Clark further divided this sector into construction and craft activities (Camacho et al, 2005). The Fisher-Clark theory of stages of development suggests that as a country develops, it goes through three stages: agriculture, industrial and services. The primary (agricultural) sector diminishes as the secondary (manufacturing) sector increases. Primary production dominates low-income countries, secondary production dominates middle-income countries and a large or rising tertiary sector is a sign of economic maturity in a country's development process.

\section{Hot topic}

Hirschorn (1988) showed there is a changing relationship between goods and services; it is not the case that services have replaced goods and a country's manufacturing base has 
declined as a result. Instead, he points out that there is a different combination of goods and services in the post-industrial economy. Questions such as how a company should position itself in a product to service continuum have been raised (Oliva and Kallenberg, 2003). A high percentage of the workers in manufacturing are indeed undertaking service jobs such as management, marketing and sales. This signifies a growth in tertiarisation in the production process (Kox and Rubalcaba, 2007).

\section{Defining services}

The difficulties of discussing services arise the moment one tries to define them (Griliches, 1992). A definition of services that has widespread support is "Services are activities, deeds or processes and iterations" (Solomon et al., 1985; Lovelock, 1991; Zeithaml and Bitner, 2003). Edvardsson (2005) refers to a range of definitions in the services literature, highlighting definitions by Hill (1977): "Services are changes in the condition of a person or something in the possession of the customer"; and Lovelock (1991) - "a process or performance rather than a thing". Vargo and Lusch (2004) define services as "the application of specialized competences (knowledge and skills) through deeds, processes, and performances for the benefit of another entity or the entity itself." Grönroos (2000) points out that most of the definitions focus on the customer and how services are provided in answer to customer problems. These studies mainly indentify the role of customer in transaction due to their involvement in the process. Since the essence of professional services is the high level of technical knowledge of the professional, the level of information available to the provider and the consumer is different. In addition, the OECD (2009) suggests professional services are often credence goods, the quality of which can almost never be adequately assessed and external quality assurances may thus be required.

\section{Characteristics of a service}

Zeithaml et al. (1985) found that, between 1963 and 1983, the most frequently cited characteristics of a service in the literature are: intangibility, inseparability (simultaneous production and delivery), heterogeneity (reflecting the ability to customise the 'product') and perishability (cannot be stored or carried forward) (Regan, 1963; Rathmell, 1966; Shostack, 1977; and Zeithaml et al 1985). Other dimensions include the time and place of delivery, the level of customisation, and the role of technology. Lovelock (1992) summed up 
the characteristics of a service business as: Labour intensity, consumer interaction, and service customisation. Kotler (1991) developed four categories of goods and services. Figure 2 shows these as a continuum, ranging from a pure tangible good to a pure service (the examples from the construction sector are the authors').

\section{Figure 2 The good-service continuum}

\begin{tabular}{cccc}
\hline $\begin{array}{c}\text { A pure tangible good, } \\
\text { no services accompany } \\
\text { the product }\end{array}$ & $\begin{array}{c}\text { A tangible good with } \\
\text { accompanying services } \\
\text { e.g. a lift installation with }\end{array}$ & $\begin{array}{c}\text { A major service with } \\
\text { accompanying minor } \\
\text { goods and services }\end{array}$ & $\begin{array}{c}\text { A pure service. } \\
\text { e.g. architectural design, } \\
\text { engineering design, }\end{array}$ \\
$\begin{array}{c}\text { e.g. facilities management } \\
\text { inc supply of equipment; }\end{array}$ &
\end{tabular}

\section{Service definitions in the official statistics}

Measuring the export of services is problematical because of the fluidity and interpretation of the data. The measurement system uses an agreed definition of services according to the System of National Accounts (SNA), a framework that consists of agreed concepts, definitions and classifications. SNA (1993) definition of services is:

"Outputs produced to order and which cannot be traded separately from their production. Services are not separate entities over which ownership rights can be established. They cannot be traded separately from their production. Services are heterogeneous outputs produced to order and typically consist of changes in the conditions of the consuming units realized by the activities of producers at the demand of the consumers. By the time their production is completed they must have been provided to the consumers."

This definition is used by national statistical offices, in collecting and disseminating data on services, their value, the sectors' employment, and import and exports. Conforming to both the SNA and the internationally-recognised United Nations system - International Standard Industrial Classification (ISIC) allows cross-country/international comparisons by industry. Based on the ISIC, country/region-specific industrial classifications are used, including: the Standard Industrial Classification (SIC) in the UK, the North American Industry Classification System (NAICS) and Nomenclature Générale des Activités Économiques dans les Communautés Européennes (NACE) in Europe. 
The measurement of a service by the statistical offices relies upon the SNA definition to identify a service, as opposed to a good, and the industry classification to record the transaction or data in the correct place. The 2007 UK Standard Industrial Classification (SIC) (ONS, 20007a) classifies construction under SIC (2007) 41 (Construction of buildings), 42 (Civil engineering), 43 (Specialised construction activities), and construction services under 71 (Architectural and engineering activities; technical testing and analysis) and 74 (Other professional, scientific and technical activities), each with a number of sub-sections. Architecture covers both town and city planning and landscape architecture (ONS, 2007a) but comes under one heading of architecture in the balance of payments (ONS, 2008). However, engineering includes a wide range of services ranging from architectural engineering to geophysical, geological or acoustics. The difficulty becomes in breaking down the data into the correct sections for the purposes of supplying the data to the Office for National Statistics (ONS). For example, with engineering, procure, construct (EPC) projects, it is difficult to break down the design and services components separately from the project value.

The Pink Book lists two headings: "construction trade" and "other business services trade". Construction covers "work done on construction projects and installations by employees of an enterprise in locations outside their resident economic territory" - SIC (2007) 41-43. There are some limitations on the scope and detail of these headings. For example, with construction, if a permanent base is set up overseas and operations are likely to exceed 12 months, then transactions are treated as foreign direct investment (FDI) and are excluded. This is significant because most large consulting enterprises will establish local offices in a region with the aim of localising and winning further work in that region. Hence, this will mask the true extent of the UK influence in the export of services in statistics. If a firm chooses FDI as a means of serving its overseas markets, it is considered to become a multinational enterprise, defined as a firm that "acquires a substantial controlling interest in a foreign firm or sets up a subsidiary in a foreign country" (Markusen and Venables, 1995).

The OECD, the European Commission (through Eurostat) and a number of countries produce Foreign Affiliates Trade in Services (FATS) data, but the coverage is limited. FATS statistics are useful as 1) a focus on services, 2) measuring commercial presence and, 3) helping to understand the phenomenon of globalisation. 
The UK only produces data on inward FATS i.e. the activities of foreign affiliates operating in the UK and not the operation of foreign affiliates overseas. Yet, they are particularly applicable for CPS exports because of the tendency of large CPS organisations to set up branch offices in order to operate overseas. FATS data cover number of employees, turnover, exports and imports, and value added.

The data for this research, collected from the semi-structured interviews undertaken with large consulting engineers and a round-table discussion with industry and government representatives. The intention of construction and engineering organisations is to record their business activities either according to geographical area or by type of work (business unit). The interviewees highlighted the mismatch between how they produce their management accounts and the format in which the information and data is requested by the ONS. Cannon (1994) substantiates this industry view in her study of how well the official statistics meet the needs of the industry. She points out that the government's data collection is to provide "evidence for the ultimate management of the economy rather than statistics which should be helpful to the industry."

Interviews confirmed the view of Cannon (1994) that the industry found supplying information for official statistics was burdensome. Importantly, the companies found the output not useful because it provides a historical snapshot how UK companies are performing at an aggregate level and it is requested in a form very different to the way they collect and classify their own business data. The export data are mainly used by policy makers to ascertain a country's export performance. Construction professional services firms are interested in the overseas turnover of their competitors to benchmark themselves; they are interested in where firms are working, in what sectors and what services are being provided. Some of these data have, in the past, been available from trade organisations that collect information from their members. The lack of disaggregated statistics was recognised by the interviewees as a problem.

\section{Characteristics of a construction professional services as a hot topic}

The construction sector is heterogeneous; it covers a long and fragmented value chain. Even within construction professional services, there is a substantial difference between a company providing consulting engineering services for a nuclear power plant, and a 
landscape management company. They may be similar in size, but they differ in levels of technology, the skills set of their staff, and their competencies. One thing all construction professional service organisations have in common is that they provide Knowledge Intensive Business Services (KIBS) and concentrate on their inputs of technology and human capital (Styles et al, 2005). KIBS are defined by Miles et al. (1995) as "services which rely heavily upon professional knowledge, and either supply products which are themselves primarily sources of information and knowledge to their users, or use their knowledge to produce services which are intermediate inputs to their clients' own knowledge generating and information processing activities, having other businesses as their main clients." KIBS are an important part of a knowledge-based economy, which responds to globalisation through a strong record of exporting (Ofori, 2003)

Miles et al. (1995) describe professional services as "services which rely heavily upon professional knowledge, and either supply products which are themselves primarily sources of information and knowledge to their users". A construction professional service fits this description but there is greater benefit in focusing on the characteristics in order to distinguish one service from another (Gershuny \& Miles, 1983). Their characteristics better reflect their mode of production and delivery.

A number of researchers have considered the characteristics of the firm and the relationship with the customer rather than just the service provided (Bell, 1973; Shostack, 1977; Lovelock, 1980; Maister \& Lovelock, 1982; Løwendahl, 2007; Liu et al, 2008). Løwendahl (2007) suggests a number of typical characteristics of professional services firms. These are "based on the 1960s sociological literature on professions and professionals and interviews with a number of executives" (Løwendahl, 2007):

- Knowledge intensive

- Involves professional assessment and judgement

- Highly customised

- High degree of interaction

- Professional training

- Constrained by professional norms 
Our research suggests that two more should be added for CPS firms: heterogeneity and location specificity. Heterogeneity is substantiated by the range of construction professional services in the standard industry classification taxonomy - see Table 1.

Table 1

UK Standard Industrial Classification of Economic Activities 2007 (SIC 2007)

\section{ARCHITECTURAL AND ENGINEERING ACTIVITIES; TECHNICAL TESTING AND ANALYSIS}

71 Architectural
and engineering
activities;
technical testing
and analysis

71.1 Architectural and engineering activities and related technical consultancy

71.11 Architectural activities

71.11/1 Architectural activities

71.11/2 Urban planning and landscape architectural activities

71.12 Engineering activities and related technical consultancy

71.12/1 Engineering design activities for industrial process and production

71.12/2 Engineering related scientific and technical consulting activities

71.12/9 Other engineering activities (not including engineering design for industrial process and production or engineering related scientific and technical consulting activities)

71.2 Technical testing and analysis

74 Other professional, scientific and technical activities

\subsection{Specialised design activities}

74.10 Specialised design activities

74.9 Other professional, scientific and technical activities n.e.c.

74.90 Other professional, scientific and technical activities n.e.c.

74.90/1 Environmental consulting activities

74.90/2 Quantity surveying activities

74.90/9 Other professional, scientific and technical activities (not including environmental consultancy or quantity surveying)

These wide-ranging activities are delivered to a broad spectrum of customers, from small to medium to large (either in the public or private sector) and a variety of types of construction such as residential, non-residential, civil engineering, heavy engineering and so on. Location specifity reflects the project specific nature of CPS.

Whilst the characteristics are useful to understand the nature of CPS, they need to be considered in the context of the project-based nature of construction. Consider a 2-year bridge project in Turkey. The project will involve construction services (building the bridge) and a wide range of CPS, from seismic surveys, to architectural engineering, to planning. The majority of transactions from the project will be reported by individual firms, but as the project duration is longer than a year, they will be treated in the national statistics as a 
foreign direct investment, not an export. Furthermore, the transaction will "be allocated to the most important mode in terms of time and resources associated with it" (UN, 2002). Some of the CPS provided may originate from the local branch office of the CPS firm and only part of the revenue remitted back to the parent company.

\section{The changing environment of CSEs}

The changing environment in which CPS organisations operate can be classified under 2 main headings. These changes have significant impact on export data in national and international statistics. This section investigates these shifts and conclude with recommendations for improvement.

\section{Globalisation}

The OECD (2002) has stated that: "the share of production (or turnover) stemming from outside a country's borders is one of the most relevant indicators for measuring the scale of globalization - not only at global and sectoral levels, but also at the level of the individual firm. In some sectors, the said output is often twice as high as the value of the exports, which shows that, in order to penetrate a market, direct investment may be a more important instrument than exports."

Globalisation has led to a changing geography of foreign ownership with mergers and acquisitions. Many of the major CPS companies have overseas shareholders and Board members, creating complex global financial and business links. Of the top 20 consulting engineers (registered in the UK) in the New Civil Engineer's 2009 Top Consultants file, 5 are overseas firms (NCE, 2009). This contrasts with none in 1995. Foreign ownership can complicate the collection of statistics, particularly where money is remitted back to the parent company. Several interviewees explained that their branch offices were autonomous and the head office 'top sliced' the revenue from each of its overseas operations.

\section{Procurement}

Evolving procurement strategies complicate the understanding of services exports. PublicPrivate partnerships, BOT and design and build all involve several organisations and a high 
degree of sub-contracting, which can involve a large number of small firms. Lu and Sexton (2006) point out that the majority of construction professional service firms are small companies; the UK is no exception. The roundtable discussions highlighted a concern that the SMEs were not being included in the export statistics, yet, the knowledge-intensive nature of the sector and the advances in ICT, mean that small consultants are able to operate internationally.

Joint ventures and strategic alliances are a major strategy for many companies, for global effectiveness. Outsourcing and off shoring has become increasingly popular as enterprises concentrate on their core competencies and use other agents to provide business services. Examples of this are CAD design offices located in developing countries such as China, Pakistan, and India. The office undertakes the design work using CAD systems located anywhere in the world; the driver is the lower cost of production with lower wage costs and overheads. These contribute to further complexities in data collection as the parent company may aggregate the project income as it is remitted by the overseas office. Their accounts reflect the work of the head office and, if applicable, their overseas office(s) if they are set up as a 'legal entity'.

\section{Recommendations}

The following recommendations are an attempt to address the gaps identified by the research in the construction professional services data.

Recommendation 1: Outward FATS statistics are needed to give a more accurate picture of UK CPS exports and this is only possible with close-up studies on delivery methods and characteristics of services in construction.

Recommendation 2 Consideration should be given to the production of joint statistics construction services and construction professional services - that reflect the project-based nature of construction.

These recommendations form the bases of the next phase in the research. 


\section{Conclusions}

Construction professional services (CPS) represent an important part of the UK's growing positive balance of trade in services. Understanding their global spread and breadth in scope is essential. However, the definitions of services in the literature are generic due to their complex delivery modes and intangible and heterogenic structure.

The emerging business environment of CPS, mostly due to the effects of globalisation, and more recently, the global economic recession, prompts the need for a better definition of CPS characteristics and classification. The measurement of CPS export performance is underpinned by the definitions and classifications used in national and international statistics. Yet, these classifications fail to reflect the changing landscape of CPS exports as they are activity specific. Our study reviewed the definitions of service activities over time and developed specific CPS characteristics. The multiplicity of export strategies that CPS firms adopt has been listed and the gaps between the 'theoretical' definitions and the reality of CPS business today highlighted. In the view of the selected architectural, engineering and surveying companies, the construction professional services data do not reflect how the sector operates overseas. The data are highly aggregated and do not take account of the project-based nature of the work or adequately distinguish between sub sectors. Based on this, the two recommendations in the previous section were developed.

According to the OECD (2008), "there is no unified statistical system to quantify the various modes of service provision at the international level". Based on this, and the concerns highlighted in the data collection phase, two recommendations were put forward. The first is about what data is collected and the second is about the output of the data. Taking action on these recommendations involves further research, which is being undertaken by the authors. The research is into: better classifications to inform a more reliable calculation of the growth of construction professional services; the use of cross-classification to produce more appropriate data, and; how the data could be collected in a more disaggregated form to provide better information for the industry and the policy makers. 


\section{References}

Andersen, B. and Corley, M. (2002) The theoretical, conceptual and empirical impact of the service economy: a critical review. DRUID Summer Conference on "Industrial Dynamics of the New and Old Economy - who is embracing whom?" Copenhagen/ Elsinore

Bell, D. (1973) The coming of the Post-Industrial Society, Basic Books, New York.

Beyers, W.B. (1985) Export service in post-industrial society Papers of the Regional Science Association, Vol 57 1985, Illinois, USA

Brook, K. (2008) Developments in measuring the UK service industries, 1990-2006. Economic and Labour Market Review, 2(1), 18-29.

Camacho, J.A., Navarro, J.L. and Rodriguez, M. (2005) From structural change to the global production system. A review of the evolution of service activities. $\mathrm{XV}^{\text {th }}$ International RESER Conference. Granada, September 22-24.

Cannon, J. (1994) Lies and construction statistics. Construction Management and Economics 12, 307-313.

Clark, C. (1940) The Conditions of Economic Progress, Macmillan: London.

Edvarsson, B., Gustafsson, A. and Roos, I. (2005) Service portraits in service research: a critical review. International Journal of Service Industry Management, 16(1), 107-121.

Eurostat (2007) European Union international trade in services. Analytical aspects 19972000. ISSN 1725-447, pp. 105.

Fisher, A.G.B. (1935) The Clash of Progress and Security. New York: Augustus M. Kelly.

Gershuny, J.I. and Miles, I.D. (1983) The new service economy: The transformation of employment in industrial societies, London, Francis Pinter (Publishers).

Grönroos, C. (2000) in Fisk, R.P., Grove, S.J. and John, J. (Eds), Services Marketing SelfPortraits: Introspections, Reflections, and Glimpses from the Experts, American Marketing Association, Chicago, IL, pp. 71-108.

Hill, T.P (1977) On goods and services. Review of Income and Wealth, 23(4), 315-338.

Hirschorn, L. (1988) The post-industrial economy: labour, skills and the new mode of production. Service Industries Journal, 8(1), 19-38. 
Kotler, P. (1991) Marketing management: Analysis, planning and control, Prentice Hall, Englewood Cliffs, 7th edition

Kox, H.L.M. and Rubalcaba, L. (2007) Analysing the Contribution of Business Services to European Economic Growth. Bruges European Economic Research Papers (BEER) paper No. 9 .

Liu, C.H., Wang, C.C. and Lee, Y.H. (2008) Revisit service classification to construct a customer-oriented integrative service model International Journal of Service Industry Management, 19(5), 639-661.

Lovelock, C.H. (1980) Towards a classification of services in Lamb, C.W. \& Dunne, P.M. (Eds) Theoretical Development in Marketing, American Marketing Association, Chicago.

Lovelock, C.H. (1991) Services Marketing, Englewood Cliffs, NJ, Prentice-Hall.

Lovelock, C.H. (1992) Managing Services - Marketing, operations and human resources Englewood Cliffs, NJ, Prentice-Hall.

Løwendahl, B. (2007) Strategic management of professional service firms $3^{\text {rd }}$ edn. Copenhagen: Copenhagen Business School Press.

Lu, S-L. and Sexton, M. (2006) Innovation in small construction knowledge-intensive professional service firms: a case study of an architectural practice. Construction Management and Economics, 24, 1269-1282.

Maister, D.H. \& Lovelock, C.H. (1982) Managing facilitator services, Sloan Management Review, 23 (3), 19-31.

Markusen J.R. and Vanables, A.J. (1995) The increased importance of multinationals in North American economic relationships: a convergence hypothesis" (in) Canzoneri, M.W., Ethier W.J. and Grilli V. (eds) The New Transatlantic Economy, London, Cambridge University Press.

Marx, K. (1863) Theories of Surplus Value. Moscow, Progress Publishers.

Melvin, J.R. (1995) History and measurement in the service sector: a review. Review of Income and Wealth, 41(4).

Miles, I., Kastrinos, N., Bilderbeek, R., den Hertog P., Flanagan, K. and Huntink, W. (1995) Knowledge-intensive business services: their role as users, carriers and sources of innovation, Report to the EC DG XIII Sprint EIMS Programme, Luxembourg, 1995.

NCE (2009) New Civil Engineer Consultants' File 2009 Emap Ltd $18^{\text {th }}$ March 2009 ISSN 03077683. 
OECD (2002) Introduction to the Concept of Economic Globalization and its Measurement Chapter I in Measuring Globalisation: The Role of Multinationals in OECD Economies, Volume II: Services. Paris.

OECD (2005) Growth in Services: Fostering Employment, Productivity and Innovation. Meeting of the OECD Council at Ministerial Level, 2005.

OECD (2008) Globalisation in Services: From Measurement to Analysis. OECD Statistics Working Paper. STD/DOC(2008)3/REV1. OECD, Paris.

OECD (2009) Experts meeting on the services trade restrictiveness index (STRI) Services trade restrictiveness: professional services OECD, Paris, July 2009.

Ofori, G. (2003) Preparing Singapore's construction industry for the knowledge-based economy: practices, procedures and performance, Construction Management and Economics, 21(2), 113-125.

ONS (2007a) UK Standard industrial Classification of Economic Activities 2007.

ONS (2008) The Pink Book, National Statistics.

ONS (2009) Time series data, accessed from www.statistics.gov.uk.

Oliva, R. and Kallenberg, R. (2003) Managing the transition from products to services', International Journal of Service Industry Management, 14(2), 160-72.

Rathmell, J.M. (1966) What is meant by services. Journal of Marketing, 30, 32-36.

Regan, W.J. (1963) The service revolution, Journal of Marketing, 27(7), 57-62.

Ricardo (1817) On the Principles of Political Economy and Taxation. London, John Murray.

Shostack, G.L. (1977) Breaking free from product marketing, Journal of Marketing, 41(2), 73-83.

Smith A. (1776) The Wealth of Nations. London, Methuen.

Solomon, M.R., Surprenant, C.F., Czepiel, J.A. and Gutman, E.G. (1985) A role theory perspective on dyadic interactions: the service encounter, Journal of Marketing, 49(1), 99-111.

Styles, C., Patterson, P and La, V. (2005) The nature of knowledge-based services. Journal of International Marketing, American Marketing Association, 13(4), 104-128ISSN 1069-031X (print) 1547-7215 (electronic).

UN (2002) Manual on Statistics of international Trade in Services. Statistical papers series M no. 86 Published by the UN in co-operation with the European Commission (EC), the International Monetary Fund (IMF), the Organisation for Economic Cooperation and Development (OECD), United Nations Conference on Trade and 
Development (UNCTAD) and the World Trade Organization (WTO). Geneva. ISBN

92-1-161448-1

Vargo, S.L. and Lusch, R.F. (2004), Evolving to a new dominant logic of marketing, Journal of Marketing, 68 (January), 1-17.

Von Nordenflycht, A. (2009) what is a professional service firm? Towards a theory and taxonomy of knowledge intensive firms. Massachusetts Institute of Technology (MIT) - Sloan School of Management. Available at SSRN: http://ssrn.com/abstract=140734

Weissenberger-Eibl, M. and Koch, D.J. (2007) Importance of industrial services and service innovations. Journal of Management and Organization, June 2007

World Bank (2009) Reshaping economic geography. World development Report 2009. Washington, The International Bank for Reconstruction and Development/The World Bank. ISSN 01635085.

Zeithaml, V., Parasuraman, A. and Berry, L. (1985), Problems and strategies in services marketing, Journal of Marketing, 49(Spring), 33-46.

Zeithaml, V. and Bitner, M.J. (2003), Services Marketing: Integrating Customer Focus across the Firm, 3rd ed., McGraw-Hill, New York, NY. 